\title{
Effect of Lupine and Amaranth on Growth Efficiency, Health, and Carcass Characteristics and Meat Quality of Market Pigs
}

\author{
Z. ZRALÝ ${ }^{1}$, B. PÍSAŘÍKOVÁ ${ }^{1}$, M. TRČKOVÁ ${ }^{1}$, I. HERZIG ${ }^{1}$, M. JƯZL ${ }^{2}$, J. SIMEONOVOVÁ ${ }^{2}$ \\ ${ }^{1}$ Veterinary Research Institute, Brno, Czech Republic \\ ${ }^{2}$ Mendel University of Agriculture and Forestry, Czech Republic \\ Received October 27, 2005 \\ Accepted June 30, 2006
}

\begin{abstract}
Zralý Z., B. Písaříková, M. Trčková, I. Herzig, M. Jůzl, J. Simeonovová: Effect of Lupine and Amaranth on Growth Efficiency, Health, and Carcass Characteristics and Meat Quality of Market Pigs. Acta Vet Brno 2006, 75: 363-372.

The purpose of the present study was to ascertain whether it is possible to substitute animal protein in a pig diet with lupine of Sonet cultivar or amaranth grain or dried surface biomass of amaranth when one type feed ration is used during the entire period of fattening, and to investigate its impact on growth efficiency and health of pigs. Its role in feed conversion, carcass characteristics, meat quality and sensory parameters was analyzed.

Four groups of pigs ( $\mathrm{n}=10,5$ males and 5 females) with the body weight of $24 \mathrm{~kg}$ were fed semi-ad libitum for 90 days the following diets: control group (C) - diet containing $3 \%$ of fish meal, experimental group (1) - diet containing 5\% of non-heat-treated amaranth grain and 5\% of dried surface biomass of amaranth, experimental group (2) - diet containing 5\% of popped (heattreated) amaranth grain and 5\% of dried surface amaranth biomass, experimental group (3) - diet containing $10 \%$ of lupine seed meal. Animal protein substitution in diets with amaranth (group 1, 2 ) or lupine (3) did not result in significant differences $(p>0.05)$ in average daily body weight gain in comparison with the control group $(\mathrm{C}-0.83$ and $0.82,0.80$ and $0.79 \mathrm{~kg}$ in groups 1,2 and 3 , respectively). The differences in feed conversion were non-significant $(2.69$ to $2.79 \mathrm{~kg} / \mathrm{kg}$ of body weight gain). The tested diets did not adversely affect animal metabolism, and significantly lower concentrations $(p<0.05, p<0.01)$ of total protein, glucose and triacylglycerol in animals of group $\mathrm{C}$ ranged within physiological limits. No significant differences between control and experimental animals were found in carcass characteristics, meat and sensory qualities. Lupine supplementation of the diet positively affected the tenderness and taste of meat.
\end{abstract}

Animal protein, performance, feed conversion, blood biochemistry, intramuscular fat, sensory parameters

After the limitation of animal-derived feeds in animal nutrition, concern has been expressed as to what substances to use to replace the high-quality raw material previously used for the preparation of combined feeds without adverse effects on the health status and performance of fattened pigs. Although it is very difficult to replace animal protein, leguminous plants (soy, pea and lupine), oil plants (oilseed rape and sunflower) and pseudocereals (amaranth) may be considered. Predominant use of imported soy as a feed component for monogastric animals has been limited by price and moreover, heat treatment is necessary for inactivation of anti-nutrient substances. Some cultivars of soy also contain oestrogen-like substances (Sommer 2003).

It follows from the present situation that it is necessary to use vegetable feeds of inland production and of high nutritional quality that are available for a reasonable price. The seeds of lupine cultivars meet these requirements from an aspect of high protein content, adaptability to various climatic conditions and sufficient yield. According to the most recent studies, lupine has been classified as one of eight prospective protein sources for the production of feeds and foods that may replace meat in human nutrition (Dijkstra et al. 2003).

Address for correspondence:

MVDr. Zdeněk Zralý, CSc.

Veterinary Research Institute

Hudcova 70

62132 Brno, Czech Republic
Phone: +420533331612

Fax: + 420541211229

E-mail: zraly@vri.cz

http://www.vfu.cz/acta-vet/actavet.htm 
The seeds of sweet lupine cultivars (Lupinus albus, L. angustifolius, L. luteus) contain 28 to $48 \% \mathrm{~N}$-substances in dry matter, which depends on the lupine cultivar and climatic conditions (Hove 1974; Green and Oram 1983; Sousa et al. 1996; Linnemann and Dijkstra 2002). The profile of amino acids is characterized by a lower level of sulphur containing amino acids and threonine in comparison with soy (Simon and Jeroch 1999); in contrast, arginine content is markedly higher (Suchý et al. 2005). The lipid content is 5 to $13 \%$, high percentages (up to $80 \%$ ) of unsaturated fatty acids are represented by linoleic and linolenic acids ( Y anez et al. 1983) and average levels of metabolized energy for pigs are slightly lower in comparison with soy. In contrast to other leguminous plants, the lupine seed contains more crude fibre; a proportion of that is viewed as dietetically beneficial. The seed contains minute amounts of starch (5 to 12\%), higher levels of soluble non-starch polysaccharides (NSP) and alpha-galactosides that cannot be digested by endogenous enzymes; under such conditions, decreased utilization of nutrients and energy, disturbed health status and low performance of pigs have been recorded (Batterham 1992; Gdala et al. 1997 et al.). The content of anti-nutrient substances, particularly quinolizidine alkaloids, markedly decreased in new sweet lupine cultivars in comparison with bitter cultivars (Aniszewski et al. 2001). The content of other anti-nutrient substances (trypsin and chymotrypsin inhibitors, tanins, phenolic substances, lectins etc.) is relatively low and the seeds of these cultivars do not require heat treatment and may be fed unprocessed to the animals.

It was confirmed in animal experiments that amaranth contains high-quality protein. However, in some cases, the variables of growth efficiency obtained were lower than expected (Correa et al. 1986; Imeri et al. 1987). The possibility to use autoclaved grain for chickens was tested by Acar et al. (1988), the effects of extruded amaranth grain in feed rations were investigated by Tillman and Waldroup (1987) and nutritional quality of the surface biomass was studied in lambs by Pond and Lehmann (1989). However, available literature data on the amaranth use in pig nutrition are scarce (Sokól et al. 2001; Zralý et al. 2004).

The purpose of the present study was to ascertain whether it is possible to substitute animal protein in a pig diet with lupine of the Sonet cultivar and amaranth, using one type feed ration during the entire period of fattening, and its impact on the pigs' growth efficiency and health, carcass characteristics and meat quality.

\section{Materials and Methods}

Forty Large White x Landrace pigs in equal numbers of barrows and gilts (mean live weight $24.4 \pm 1.70 \mathrm{~kg}$ ) were used. The animals were marked by tattooing. Experimental animals were housed in pens of 10 pigs each, under good hygienic conditions of accredited animal facilities at the Veterinary Research Institute. Average surface space was $1.7 \mathrm{~m}^{2}$ and the length of the feeding place was $0.3 \mathrm{~m}$ per pig. Straw was used as bedding.

Conditions of animal hygiene were monitored by continuous measurements of ambient temperature and relative humidity. Average morning and evening ambient temperatures in pig stables were $20.8 \pm 2.4^{\circ} \mathrm{C}$ and $22.4 \pm 2.3{ }^{\circ} \mathrm{C}$, respectively; average relative humidity was $53.5 \pm 5.9 \%$ and $57.1 \pm 6.6 \%$, respectively.

The experiment was preceded by an 11-day pre-treatment period, during which the pigs gradually adapted to the new diet and environment, and concurrently their performance and growth uniformity were monitored. They were preventively dewormed (Ivomec, inj.; MSD, Agvet, USA) during that period with doses according to the manufacturer's instructions.

Before biological testing commenced, the animals were weighed, and based on individual live weight, they were allocated to four groups (5 males and 5 females in each). Average weight of pigs in respective groups ranged between $24.2 \pm 1.4$ and $24.8 \pm 1.8 \mathrm{~kg}$. Variation coefficient $(<10 \%)$ was consistent with the requirements of biological testing (Anonymous 2004).

Experimental diets were based on cereals (wheat and barley) and comprised extracted soy meal, $46 \%$ crude protein (CP) and feed supplements. Control group diet (C) contained 3\% of fish meal. The diets for three experimental groups contained $5 \%$ of amaranth flour and $5 \%$ of dried green surface amaranth biomass (1), 5\% of popped (heat-treated) amaranth grain and 5\% of dried green surface amaranth biomass (2) or $10 \%$ of dehulled ground lupine seed of theSonet cultivar (3). Compositions of experimental diets are given in Table 1 . The diets were 
suggested for fattening of meat type pigs with $56 \%$ proportion of lean musculature (Šimeček et al. 1993). The diets were analysed for the content of basic nutrients using laboratory procedures for testing the feeds (Anonymous 2000).

The diets were mixed with drinking water $1: 1$ and fed to each group of pigs twice a day during the experimental period (90 days), partially ad libitum. Water was available ad libitum.

The amounts of feed were regulated according to the current intake and the weight of the animals in order to reduce food refusals. Thirty minutes after the beginning of feeding, the refusals were removed, weighed and taken into account in subsequent calculations.

Individually identified pigs were weighed at the beginning of the trial and then at one-week intervals. Individual and group body weight gains and relative growth rates were calculated from the detected live body weight of the animals according to Karakoz (1986). Feed conversion was calculated from feed consumption and the body weight gains of respective groups of animals.

At the beginning and the end of the trial, blood samples were drawn from $v$. cava cranialis for biochemical analysis. Total protein (TP), albumin (Alb), glucose (Glu), triacylglycerols (TG), cholesterol (Chol), HDL and LDL lipoproteins, alkaline phosphatase (ALP), aspartate and alanine aminotransferases (AST, ALT), calcium (Ca), and phosphorus (P) blood plasma levels were determined using Bio-La-Tests (PLIVA - Lachema Brno Ltd., Czech Republic). The health status of animals was monitored daily by observation at regular intervals. Occasional morbidity and mortality were recorded.

All experimental animals were slaughtered in an experimental slaughterhouse using electrical stunning and exsanguination. Carcass quality of slaughtered animals was assessed using the following criteria: dressing percentage, estimated lean yield in percent (ZP method, ČSN 4661 60), backfat thickness and musculus longissimus lumborum et thoracis (MLLT) depth were measured with a slide gauge at the location of the last thoracic vertebra. At the same location of MLLT, $\mathrm{pH}$ values $1\left(\mathrm{pH}_{1}\right)$ and 24 hours $\left(\mathrm{pH}_{24}\right)$ after slaughter were measured using WTW 720 pH meter (Inolab, BRD). Dry matter, crude protein (N x 6.25) and fat content (petrolether extraction in Soxhlet's extraction equipment for $6 \mathrm{~h}$ ) were determined in MLLT.

The samples (app. $500 \mathrm{~g}$ ) of muscle tissue were collected from MLLT for analyses of sensory parameters. Evaluation was done by a group of 8 members meeting the requirements of ISO 8586-1 in a special room for analysis of sensory parameters (according to ISO 8589). A five-point scale was used (1 - the least desirable, 5 - the most desirable). The following attributes (descriptors) of meat were assessed: colour, texture, juiciness, odour and taste.

The results obtained were processed by statistical methods using statistical and graphic software STAT Plus (Matoušková et al. 1992). Basic statistical data such as the arithmetic average (x) and standard deviation (SD) were calculated. Student's $t$-test was used for the evaluation of significance of differences between the detected averages $(* p<0.05, * * p<0.01)$.

\section{Results and Discussion}

The investigation of the respective diet effects on selected performance and health characteristics was conducted under objective conditions. The contents of $\mathrm{N}$-substances and MEp ranged between 170.7 and $174.2 \mathrm{~g} / \mathrm{kg}$, and 13.1 and $13.3 \mathrm{MJ} / \mathrm{kg}$, respectively. The lysine/MEp ratio was identical for all the diets $(0.83 \mathrm{~g} / \mathrm{MJ})$. Table 1 shows the content of other nutrients. Both the control and experimental diets were isoproteinic and isoenergetic.

The Sonet lupine analysis performed in this study showed that the content of $\mathrm{N}$-substances was $360.0 \mathrm{~g} / \mathrm{kg}$ in $100 \%$ of dry matter; which increased by $24.4 \%(448.1 \mathrm{~g} / \mathrm{kg})$ after the dehulling of the lupine seed. These values are in concord with the nutrient contents published by Suchý et al. (2005). The nutrient profile of lupine is similar to that of extruded ground soy (Zeman et al. 1995), and its nutritional value for monogastric animals is high.

The live body weight of control and experimental animals at the beginning of the experiment was steady and variation coefficients were adequate $(v=5.8$ to $7.6 \%)$. The live body weight and average body weight gains on days 30,60 and 90 of experiment are presented in detail in Table 2. The total body weight gain was $74.6 \mathrm{~kg}$ in the control group and 73.5, 72.1 and 71.4 kg in experimental groups 1 to 3, respectively. Differences between groups were non-significant. The following average daily weight gains in these groups were: $0.83,0.82,0.80$ and $0.79 \mathrm{~kg}$, respectively, and relative growth rates were: $300.8,302.4$, 297.9 and $294.0 \%$, respectively. The results of the present study corresponded to the results obtained by Sokól et al. (2001) who included $25 \%$ of amaranth flour or popped amaranth grain into the diets, and to the results from our previous study (Zralý et al. 2004). The highest growth intensity was recorded between days 31 and 60 of the experiment. Significant 
Table 1. Composition and nutrient contents in the diets

\begin{tabular}{|c|c|c|c|c|}
\hline \multirow[t]{2}{*}{ Components (\%) } & \multicolumn{4}{|c|}{$\operatorname{Diet}^{1}$} \\
\hline & $\mathrm{C}$ & 1 & 2 & 3 \\
\hline Barley & 40.00 & 30.00 & 30.00 & 30.00 \\
\hline Wheat & 43.00 & 42.70 & 42.90 & 48.60 \\
\hline Extracted soy meal $46 \% \mathrm{CP}$ & 11.00 & 14.30 & 14.20 & 8.20 \\
\hline Fish meal $64 \% \mathrm{CP}$ & 3.00 & - & - & - \\
\hline Amaranth DAB ${ }^{2}$ & - & 5.00 & 5.00 & - \\
\hline Amaranth $\mathrm{GAG}^{2}$ & - & 5.00 & - & - \\
\hline Amaranth $\mathrm{PAG}^{2}$ & - & - & 5.00 & - \\
\hline Lupine & - & - & - & 10.00 \\
\hline Lysine $60 \%$ & 0.12 & 0.06 & 0.06 & 0.18 \\
\hline Methionine $40 \%$ & - & - & - & 0.05 \\
\hline Threonine $20 \%$ & 0.10 & 0.05 & 0.05 & 0.10 \\
\hline Ground limestone & - & - & - & 0.10 \\
\hline Unimak P1-M ${ }^{3}$ & 2.80 & 2.80 & 2.80 & 2.80 \\
\hline \multicolumn{5}{|l|}{ Nutrients (g/kg) } \\
\hline Dry matter & 893.2 & 899.8 & 893.8 & 883.7 \\
\hline Nitrogenous substances & 171.2 & 174.2 & 170.7 & 170.0 \\
\hline Fat & 19.1 & 19.2 & 19.8 & 22.6 \\
\hline Fibre & 31.7 & 40.4 & 38.2 & 27.9 \\
\hline Ash & 53.9 & 51.0 & 47.8 & 42.8 \\
\hline Total & 275.9 & 284.8 & 276.5 & 266.2 \\
\hline $\mathrm{N}-\mathrm{FE}^{4}$ & 617.3 & 615.0 & 617.3 & 621.5 \\
\hline $\mathrm{OM}^{5}$ & 839.3 & 848.8 & 846.0 & 840.9 \\
\hline $\operatorname{MEp}(\mathrm{MJ} / \mathrm{kg})^{6}$ & 13.2 & 13.1 & 13.1 & 13.3 \\
\hline Lysine /MEp (g./MJ) & 0.83 & 0.83 & 0.83 & 0.83 \\
\hline
\end{tabular}

${ }^{1} \mathrm{C}$ - control diet $1-\mathrm{DAB}+\mathrm{GAG}$

$2-\mathrm{DAB}+\mathrm{PAG}$

3 - lupine

${ }^{2} \mathrm{DAB}$ - dried surface amaranth biomass $\quad \mathrm{GAG}$ - ground amaranth grain $\mathrm{PAG}$ - popped amaranth grain

${ }^{3}$ Commercial supplement contained the following per kg: 335000 IU vitamin A, 45000 IU vitamin D, $125 \mathrm{mg}$ vitamin K, $2665 \mathrm{mg}$ vitamin E, $5.3 \mathrm{mg}$ vitamin B ${ }^{1}, 165 \mathrm{mg}$ vitamin $\mathrm{B}^{2}, 14 \mathrm{mg}$ vitanmin $\mathrm{B}^{6}, 1.10 \mathrm{mg}$ vitamin $\mathrm{B}^{12}$, $165 \mathrm{mg}$ niacin, $250 \mathrm{mg}$ pant. calcium, $1000 \mathrm{mg}$ cholinchlorid, $0.8 \mathrm{mg}$ biotin, $6600 \mathrm{mg}$ vitamin C, $110 \mathrm{~g} \mathrm{~L}-1 \mathrm{ysine}$

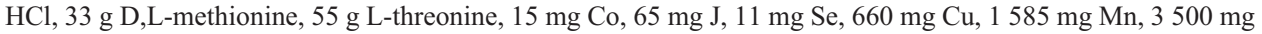
Zn, 2080 mg Fe, 56 g Na, 12 g Mg, 80 g P, 205 g Ca, 833 mg Endox, 11250 mg Bio-plus 2B,

$2900 \mathrm{mg}$ Natuphos 5 000G, $665 \mathrm{mg}$ Sacharin

${ }^{4} \mathrm{~N}-\mathrm{FE}$ - nitrogen-free extracts

${ }^{5}$ OM-organic matter

${ }^{6}$ MEp-metabolizable energy

differences $(p<0.05)$ were found between experimental groups 1 and $2(0.97 \pm 0.06$ and $0.89 \pm 0.05 \mathrm{~kg} / \mathrm{head} /$ day $)$. The average body weight gains in the control group and group 3 were lower by 3.5 and $4.2 \%$, respectively $(0.94 \pm 0.07$ and $0.93 \pm 0.05 \mathrm{~kg} / \mathrm{head} / \mathrm{day}$, respectively). Lower performance of experimental group 2 fed a diet containing $5 \%$ of popped amaranth grain can be explained by a decreased digestibility of nutrients after heat treatment. Due to the technological treatment, essential amino acids may degrade and consequently their content may be decreased or changed into a racemic compound; nondigestible complexes of fibre components with proteins or amino acids may also be formed (Bressani et al. 1987; Tovar et al. 1989).

The average consumption of the diet per head and day was $2.26 \mathrm{~kg}$ in the control group and $2.20,2.22$ and $2.21 \mathrm{~kg}$ in the experimental groups 1 to 3 , respectively. The control diet conversion was $2.72 \mathrm{~kg}$ per kg of body weight gain and the conversion of experimental diets was $2.69,2.77$ and $2.79 \mathrm{~kg}$, respectively. A slightly lower performance of the experimental group 3 fed the diet containing $10 \%$ of lupine might be explained after analysis of essential 
Table 2. Growth performance of pigs fed different diets $(\mathrm{kg})$

\begin{tabular}{|l|c|c|c|c|c|c|c|c|c|}
\hline & $\begin{array}{c}\text { Live } \\
\text { weight }\end{array}$ & $\begin{array}{c}\text { Live } \\
\text { weight }\end{array}$ & $\begin{array}{c}\text { Weight } \\
\text { gain }\end{array}$ & $\begin{array}{c}\text { Live } \\
\text { weight }\end{array}$ & $\begin{array}{c}\text { Weight } \\
\text { gain }\end{array}$ & $\begin{array}{c}\text { Weight } \\
\text { gain }\end{array}$ & $\begin{array}{c}\text { Live } \\
\text { weight }\end{array}$ & $\begin{array}{c}\text { Weight } \\
\text { gain }\end{array}$ & $\begin{array}{c}\text { Weight } \\
\text { gain }\end{array}$ \\
\hline Diet $^{1}$ & Day 0 & Day 30 & $0-30$ & Day 60 & $31-60$ & $0-60$ & Day 90 & $61-90$ & $0-90$ \\
\hline $\mathbf{C}$ & & & & & & & & & \\
\hline Mean & 24.8 & 45.5 & 20.7 & 73.9 & 28.4 & 49.1 & 99.4 & 25.5 & 74.6 \\
\hline \pm SD & 1.80 & 3.87 & 2.52 & 5.90 & 3.71 & 4.76 & 6.06 & 4.28 & 4.74 \\
\hline Index \% & 100 & 100 & 100 & 100 & 100 & 100 & 100 & 100 & 100 \\
\hline & & & & & & & & & \\
\hline $\mathbf{1}$ & & & & & & & & & \\
\hline Mean & 24.3 & 43.1 & 18.8 & 72.3 & $29.2^{\mathrm{a}^{*}}$ & 48.0 & 97.8 & 25.5 & 73.5 \\
\hline \pm SD & 1.83 & 4.95 & 3.60 & 6.22 & 2.15 & 4.97 & 8.02 & 4.58 & 7.21 \\
\hline Index \% & 98.0 & 94.7 & 90.0 & 97.8 & 102.8 & 97.8 & 98.4 & 100 & 98.5 \\
\hline & & & & & & & & & \\
\hline $\mathbf{2}$ & & & & & & & & & \\
\hline Mean & 24.2 & 44.6 & 20.4 & 71.4 & 26.8 & 47.2 & 96.3 & 24.9 & 72.1 \\
\hline \pm SD & 1.42 & 2.07 & 1.90 & 4.09 & 2.70 & 3.86 & 5.87 & 3.11 & 6.05 \\
\hline Index \% & 97.6 & 98.0 & 97.6 & 96.6 & 94.4 & 96.3 & 96.9 & 97.6 & 96.6 \\
\hline & & & & & & & & & \\
\hline $\mathbf{3}$ & & & & & & & & & \\
\hline Mean & 24.3 & 43.3 & 19.0 & 71.3 & 28.0 & 47.0 & 95.7 & 24.4 & 71.4 \\
\hline \pm SD & 1.64 & 4.90 & 3.55 & 7.80 & 3.68 & 6.51 & 9.72 & 4.22 & 8.69 \\
\hline Index \% & 98.0 & 95.2 & 90.9 & 96.5 & 98.6 & 95.7 & 96.3 & 95.7 & 95.7 \\
\hline
\end{tabular}

${ }^{1} \mathrm{C}-$ control diet $\quad 1-\mathrm{DAB}+\mathrm{GAG}$

$\mathrm{a}^{*} p<0.05$ significant difference between diet 1 and 2

$2-\mathrm{DAB}+\mathrm{PAG}$

3- lupine

amino acids, particularly limiting methionine, lysine and threonine (Batterham 1992; Gdala et al. 1997).

The health status of animals was investigated both clinically and biochemically by the analysis of blood plasma. At the beginning of the experiments, selected biochemical indices ranged within physiological values and gave evidence of a good homogeneity of the experimental groups. The effect of the diets on blood variables is presented in Table 3 . Nonsignificant differences in albumin, cholesterol and inorganic phosphorus levels, AST and ALP activities were detected. The TP content was significantly decreased in the control group in comparison with groups 1 and 3 ( $p<0.05$ and $p<0.01$, respectively); Glu was likewise decreased in comparison with group $1(p<0.05)$. Highly significant differences were found for TG levels in control group in comparison with groups 1 and $3(p<0.01)$ and group 2 ( $p<0.05 ; 0.22$ and $0.30 \mathrm{mmol} / \mathrm{l}$, respectively); HDL level in group $\mathrm{C}$ was also significantly decreased in comparison with group $2(p<0.05 ; 0.56$ and $0.64 \mathrm{mmol} / \mathrm{l}$, respectively). The AST activity detected in all the groups of animals was below the upper reference limit given by Tlučhoř (2001). Calcium concentration was at the upper limit of physiological range in all the groups. It follows from the blood plasma TG levels that no hypolipidemic effect of amaranth was recorded in contrast to Grajeta (1999). No clinical signs of a disease were observed and no mortality or gross changes of internal organs were recorded during the entire experiment.

The effect of the diets on selected characteristics of pig carcasses was assessed after the experiment had been completed. No significant between-group differences in dressing percentages and estimated lean yields $(p>0.05)$ were detected. The obtained values corresponded to the data described by Ševčíková et al. (2002). Backfat thickness and 


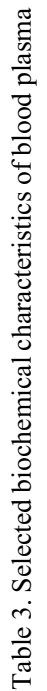

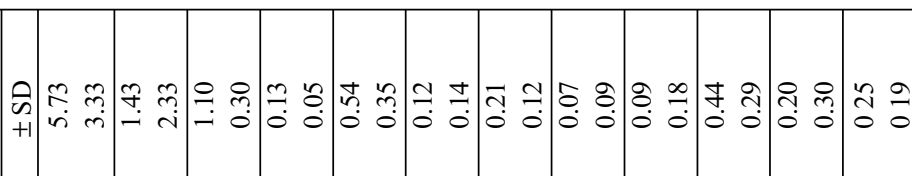

m

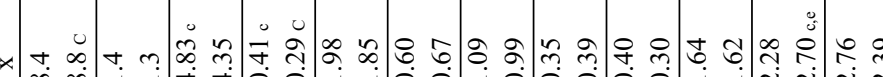

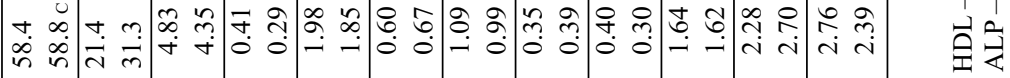

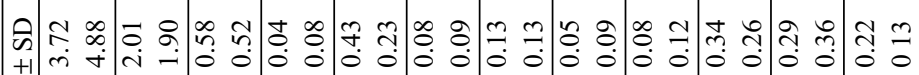

章

\begin{tabular}{llllll|l|l|l|l|l|l|l|} 
\\
\end{tabular}

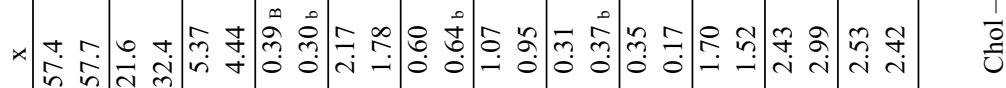

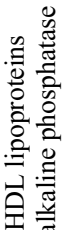

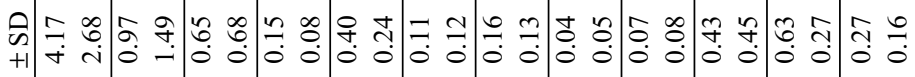

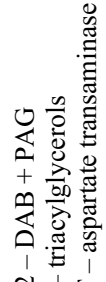

$\frac{\pi}{0}$

$n$ in $N$ m

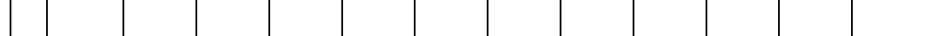

$\rightarrow$

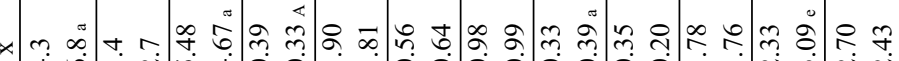

苚

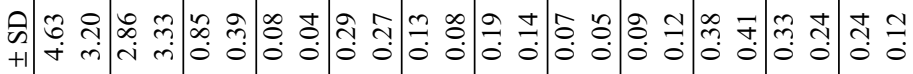

$\circlearrowright$

2

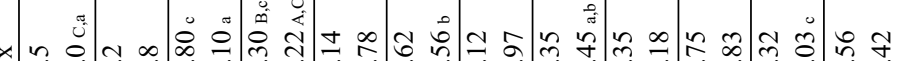

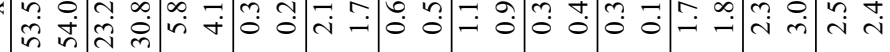

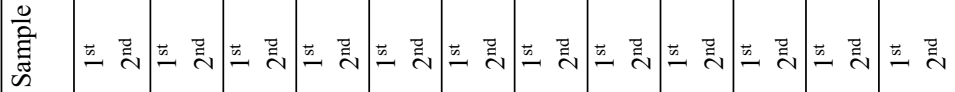

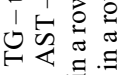

站竞

苯

ช

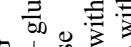

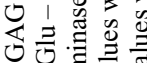

+ 雪

娄

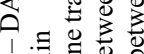

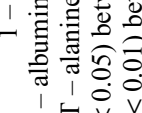

学 8

纪

원

.

\begin{tabular}{|c|c|c|c|c|c|c|c|c|c|c|c|c|c|}
\hline 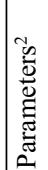 & 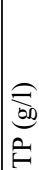 & 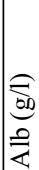 & 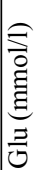 & 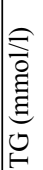 & 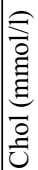 & 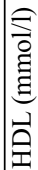 & 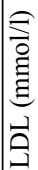 & 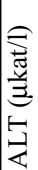 & 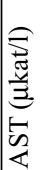 & 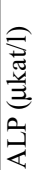 & 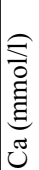 & $\begin{array}{l}\underset{\mathrm{E}}{\Xi} \\
\stackrel{\Xi}{\Xi} \\
0\end{array}$ & 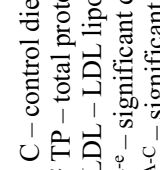 \\
\hline
\end{tabular}


MLLT depth in the control group were almost identical with groups of animals fed amaranth or lupine containing diets (Table 4). The above-mentioned carcass characteristics corresponded to the findings of Cannon et al. (1992) and Leikus et al. (2002) who did not find any differences when using various diets supplemented with soy, field beans and sweet lupines. The average $\mathrm{pH}_{1}$ and $\mathrm{pH}_{24}$ values ranged between 6.38 and 6.51 , and 5.32 and 5.42, respectively. The between-group differences were nonsignificant. The data obtained in the present study ranged within values indicating standard meat quality and were in agreement with Oliver et al. (1993) and Še včíková et al. (2002).

The results of physical and chemical analyses of MLLT (dry matter, crude protein) did not show any significant effect of experimental diets on meat composition, and corresponded to the findings of various authors (Naděje et al. 2000; Ševčíková et al. 2002). The content of intramuscular fat ranged between 1.84 and $2.22 \%$ and approached the requirement for optimum sensory parameters of pork defined by Fernandez et al. (1999). The intramuscular fat content was significantly lower $(p<0.05)$ in experimental group 2 in comparison with animals fed the lupine containing diet (group 3).

Table 4. Carcass characteristics of pigs fed different diets

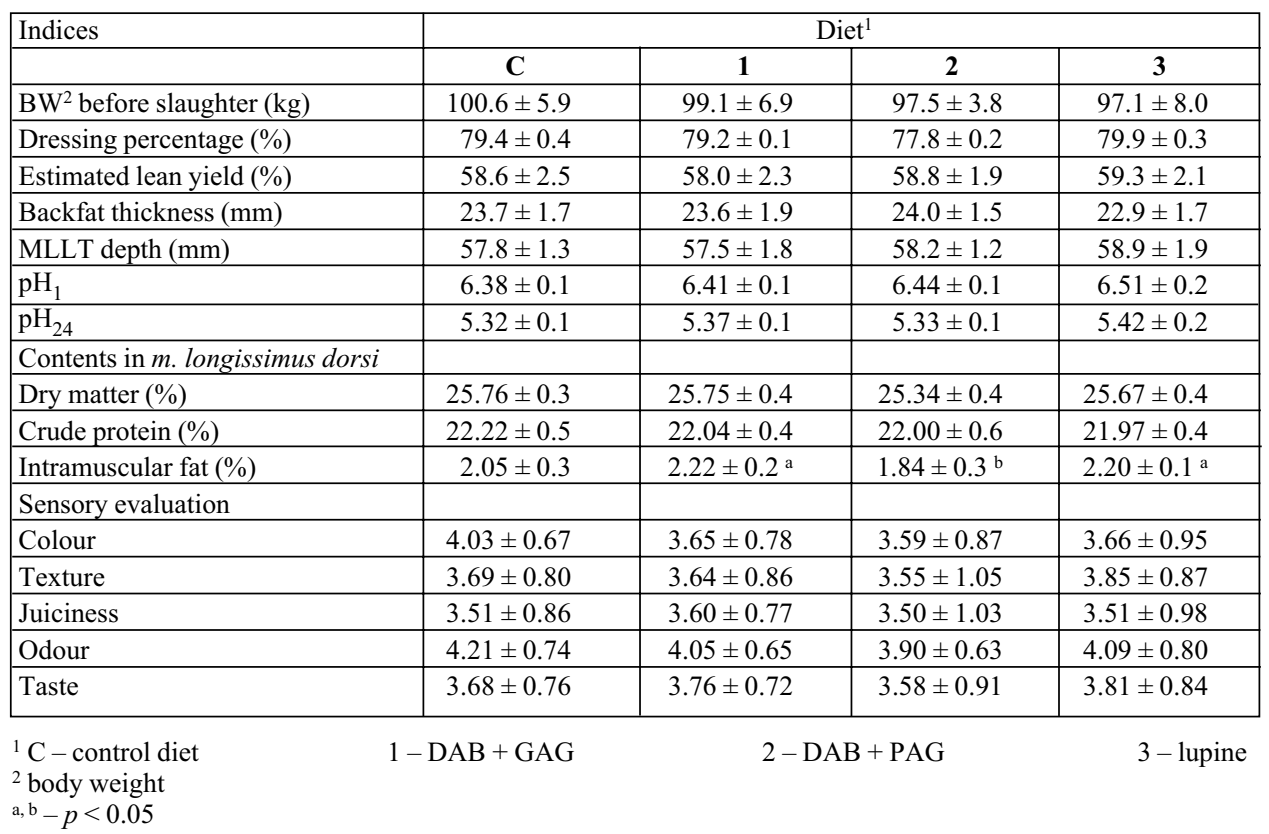

No statistically significant differences $(p>0.05)$ were obtained by the analysis of all five selected sensory parameters from the viewpoint of sex of the animals (Table 4). Colour, texture and odour of meat from gilts more approached the requirements than meat from barrows. Meat from barrows was slightly more juicy and palatable than meat from gilts. Comparison of the results of sensory analysis from an aspect of the effect of the used diets without respect to sex, no significant differences $(p>0.05)$ were found in any of the investigated descriptors (Table 4). The lightest colour of meat and the best odour was found in the control group fed a diet supplemented with animal protein (fish meal). The juiciest 
meat was obtained from animals of experimental group 1 given a diet containing non-heat treated amaranth grain. Meat from experimental animals of group 4 fed a diet supplemented with $10 \%$ of dehulled lupine showed to be the most tender (most demanded) and most palatable. References concerning the effect of tested raw materials used for feeding, on sensory parameters of meat are scarce. Sokól et al. (2001) investigated the effect of amaranth on sensory parameters of meat; they did not find any difference in meat from pigs fattened in a standard way and pigs fed diets supplemented with $25 \%$ of amaranth. Leiku s et al. (2004) detected reduced meat colour in animals fed diets containing 15 and $20 \%$ of white lupine, cultivar Danko, in comparison with animals fed diets containing $18 \%$ of extruded soybeans or 20 and $25 \%$ of field beans. It follows from the present study that no adverse effects from the aspect of consumer's demands for meat sensory parameters were detected in any of the tested diets. A beneficial effect of lupine on tenderness and taste of meat was shown.

It follows from the data obtained by evaluation of growth performance of pigs, feed conversion, health status, carcass and meat quality, including sensory parameters that animal protein may be replaced with vegetable protein, in this case with lupine and amaranth. Due to a decreased effectiveness of the lupine containing diet, more detailed analysis of amino acid profile from the aspect of limiting amino acids will be necessary.

\section{Vliv lupiny a amarantu na užitkovost, zdraví, jatečnou hodnotu a kvalitu masa výkrmových prasat}

Cílem práce bylo ověřit možnost náhrady živočišné bílkoviny v dietě prasat lupinou, var. Sonet nebo amarantem ve formě zrna nebo sušené nadzemní biomasy s použitím stejné krmné směsi po celé období výkrmu a vliv na růstové schopnosti a zdraví. Dále byl posouzen vliv na konverzi krmiva, vybrané jatečné ukazatele, kvalitu masa a senzorické vlastnosti.

Čtyři skupiny prasat $(\mathrm{n}=10,5$ vepříků a 5 prasniček) v živé hmotnosti $24 \mathrm{~kg}$ bylo semiadlibitně krmeno 90 dní následujícími dietami: kontrolní skupina (C) - dieta obsahující $3 \%$ rybí moučky, pokusná skupina (1) - dieta obsahující 5\% tepelně neošetřeného amarantového zrna a 5\% sušené nadzemní biomasy amarantu, pokusná skupina (2) - dieta obsahující $5 \%$ popovaného (tepelně ošetřeného amarantového zrna ) a 5\% sušené nadzemní biomasy amarantu, pokusná skupina (3) - dieta obsahující 10\% lupinového šrotu. Substitucí animálního proteinu $\mathrm{v}$ dietách amarantem $(1,2)$ nebo lupinou (3) nebyl prokázán signifikantní rozdíl $(p>0.05)$ v průměrném denním přírůstku proti kontrolní skupině $(\mathrm{C}$ 0.83 a $0.82,0.80$ a $0.79 \mathrm{~kg}$ pro skupiny 1 až 3 ), neprůkazné rozdíly byli v konverzi krmiva (2.69 až $2.79 \mathrm{~kg} / \mathrm{kg}$ přírůstku). Testované diety neměly negativní vliv na metabolismus zvířat, signifikantně nižší koncentrace $(p<0.05, p<0.01)$ celkové bílkoviny, glukózy a triacylglycerolu u kontrolních zvířat byly v rozsahu fyziologických limitů. Nebyly zjištěny průkazné rozdíly mezi kontrolními a pokusnými zvířaty v ukazatelích jatečné hodnoty, kvalitě a senzorických vlastnostech masa. Pozitivně byl hodnocen vliv lupiny na křehkost a chut masa.

\section{Acknowledgements}

This work was supported by the Ministry of Agriculture of the Czech Republic, grant MZe No. 0002716201. The authors wish to thank Ing. J. Zajíc from Univit s.r.o., Olomouc, Czech Republic, for valuable recommendations and help concerning compositions of the diets.

\section{References}

ACAR N, VOHRA P, BECKER R, HANNERS GD, SAUNDERS RM 1988: Nutritional evaluation of grain amaranth for growing chickens. Poultry Sci 67: 1166-1173 
ANISZEWSKI T, CIESIOLKA D, GULEWICZ K 2001: Equilibrium between basic nitrogen compounds in lupine seeds with differentiated alkaloid content. Phytochemistry 57: 43-50

ANONYMOUS 2000: Laboratory procedures for testing the feeds additives and premixes (in Czech). ÚKZUZ, Brno, 266 p. (ISBN 80-86051-81-1).

ANONYMOUS 2004: Notice No. 184/2004, Annex 20, Ministry of Agriculture of the Czech Republic (in Czech). 6856-6863.

BATTERHAM ES 1992: Availability and utilization of amino acids for growing pigs. Nutr Res Rev 5: 1-18

BRESSANI R, CONZALES JM, ZUNIGA J, BREUNER M, ELIAS LG 1987: Yield of amaranth grain representing four species. J Sci Food Afric 38: 347-356

CANNON JE, BECHTEL PY, EASTER RA, COOK H, McKEITH FH, LESZCZYNSKI DE 1992: Effect of diet containing extruded full- fat soybeans or butter on the growth, compositions and sensory characteristics of pork. J Anim Sci 70: 3651-3656

CORREA AD, JOKL L, CARLSSON R 1986: Chemical constituents, in vitro protein digestibility, and presence of antinutritional substances in amaranth grains. Arch Latinoam Nutr 36(2): 319- 326

ČSN 4661 60: Classification of pig carcasses (in Czech). Prague, ÚNM 2000. 9 p.

DIJKSTRA DS, LINNEMANN AR, VAN BOEKEL TA 2003: Towards sustainable production of protein-rich foods: appraisal of eight crops for Western Europe. PART II: Analysis of the technological aspects of the production chain. Crit Rev Food Sci Nutr 43(5): 481-506

FERNANDEZ X, MONIN G, TALMANT A 1999: Influence of intramuscular fat content on the quality of pig meat -2. Consumer acceptability on m. longissimus lumborum. Meat Sci 53 : 67-72

GDALA J, JANSMAN AJM, van LEEUWEN P, HUISMAN J, VERSTEGEN MWA 1996: Lupins (L. luteus, $L$. albus, L. angustifolius) as a protein source for young pigs. Anim Feed Sci Tech 62(2-4): 239- 249

GRAJETA H 1999: Effect of amaranth and oat bran on blood serum and liver lipids in rats depending on the kind of dietary fats. Nahrung 43: 114-117

GREEN AG, ORAM RN 1983: . Anim Feed Sci Tech 9: 271-282

HOVE EL 1974: Composition and protein quality of sweet lupine seed. J Sci Food Agric 25: 851-859

IMERI A, FLORES R, ELIAS LG, BRESSANI R 1987: The effect of processing and amino acids supplementation on the protein quality of amaranth (Amaranthus caudatus). Arch Latinoam Nutr 37(1): 161-173

KARAKOZ A 1968: Research in animal husbandry (in Slovak). SVPL Bratislava, 352 p.

LEIKUS R, TRIUKAS K, ·VIRMICKAS G, JU·KIENE V 2004: The influence of various leguminous seeds diets on carcass and meat quality of fattening pigs. Czech J Anim Sci 49(9): 398- 406

LINNEMANN AR, DIJKSTRA DS 2002: Towards sustainable production of protein-rich foods: appraisal of eight crops for Western Europe. Part I. Analysis of the primary links of the production chain. Crit Rev Food Sci Nutr 42(4): 377-401

MATOUŠKOVÁ O, CHALUPA J, CÍGLER M, HRUŠKA K 1992: STAT Plus - user manual (in Czech). VÚVeL, Brno, $168 \mathrm{p}$.

NADĚJE B, KOUCKÝ M, ŠEVČÍKOVÁ S, ADAMEC T, LAŠTOVKOVÁ J 2000: Assessment of boar and barrow meat (in Czech). Czech J Anim Sci 45: 539-544

OLIVER MA, GISPERT M, DIESTRE A 1993: The effect of breed and halothane sensitivity on pig meat quality. Meat Sci 35: 105- 118

POND WG, LEHMANN JW 1989: Nutritive value of a vegetable amaranth cultivar for growing lambs. J Anim Sci 67: 3036-3039

SIMON O, JEROCH H 1999: Feed raw materials part 2 - the up-and- coming legumes. Feed Tech 3: 29-32

SOKÓL JL, BOBEL BK, FABIJAŇSKA M, BEKTA M 2001: Preliminary results on the influence of amaranth seeds on carcass and meat quality of fatteners. J Anim Feed Sci 10(Suppl. 2): 203-208

SOMMER A 2003: Soy in animal diets (in Czech). Krmiváfiství 4: 1-4

SOUSA IMN, MORGAN PJ, MITCHELL JR, HARDING SE, HILL SE 1996: Hydrodynamic characterization of lupine proteins: Solubility, intrinsic viscosity, and molar mass. J Agric Food Chem 44: 3018-3021

SUCHÝ P, STRAKOVÁ E, ZRALÝ Z, PÍSAŘÍKOVÁ B, TRČKOVÁ M, HERZIG I 2005: Lupine seeds as a source of protein (in Czech). Farmář 2: 37-40

ŠEVČÍKOVÁ S, KOUCKÝ M, LAŠTOVKOVÁ J 2002: Meat performance and meat quality in different genotypes of $F_{1}$ generation gilts. Czech J Anim Sci 47: 395-400

ŠIMEČEK K, ZEMAN L, HEGER J 1993: Nutrient requirement and tables of nutritional values of pig feeds (in Czech). ČAZV Pohořelice, 78 p.(ISBN 80-901598-4-2).

TILLMAN PB, WALDROUP PW 1987: Effects of feeding extruded grain amaranth to laying hens. Poultry Sci 66: $1698-1701$

TLUČHOŘ V 2001: Evaluation of biochemical parameters in veterinary medicine from the standpoint of an individual and a herd (in Czech). Krmivářství 5: 18-20

TOVAR LR, BRITO E, TAKAHASHI T, MIYAZAWA T, SORIANO J, FUJIMOTO K 1989: Dry heat popping of amaranth seed might damage some of its essential amino acids. Plant Foods Hum Nutr 39: 299-309

YANEZ E, IVANOVIC D, OWEN DF, BALLESTER D 1983: Chemical and nutritional evaluation of sweet lupines. Ann Nutr Metab 27: 513-520 
ZEMAN L, ŠIMEČEK K, KRÁSA A, et al. 1995: Tables of nutritional values of feeds (in Czech). VÚVZ Pohořelice, 465 p. (ISBN 80-901598-3-4).

ZRALÝ Z, PÍSAŘÍKOVÁ B, HUDCOVÁ H, TRČKOVÁ M, HERZIG I 2004: Effect of feeding amaranth on growth efficiency and health of market pigs. Acta Vet Brno 73: 437-444 